九州大学学術情報リポジトリ

Kyushu University Institutional Repository

\title{
Note on the ophiurans of Amakusa, Kyusyu
}

Murakami, Shiro

Amakusa Marine Biological Laboratory, Kyusyu Imperial University

https://doi.org/10.5109/22601

出版情報 : 九州大学大学院農学研究院紀要. 7 (8)，pp. 259-281，1944-06. Kyushu Imperial University バージョン：

権利関係 : 
Journal of the Department of Agriculture, Kyūsyừ Imperial University, Vol. 7, No. 8, June 15, 1944

\title{
NOTE ON THE OPHIURANS OF AMAKUSA, KYUSYU ${ }^{\prime \prime}$
}

\author{
Shiro MURAKaMI
}

As the Ophiurans of Amakusa, so far as I know, have been studied very unsatisfactorily, and a good deal of specimens have come to my hand from time to time, I think it worth while to report the result of my study on them in the present paper. The greater part of material described here was obtained by myself at Tomioka, where I am residing since 1940, as a member of the Amakusa Marine Biological Laboratory of Kyūsyū Imperial University. Some of them were found living on the shore around the Peninsula Tomioka, while the others were caught in a fishing net called "kasi-ami", used particularly for capturing the Nipponese spiny lobster (Panulirus japonicus) off the peninsula where the water is from some fifteen to forty meters deep. In addition to these, a number of specimens have been preserved at the said laboratory, being collected at Tomioka and its vicinities by Professor Dr. H. OHSHIMA and the other gentlemen. A close examination of these Ophiurans reveals no less than thirty-two species, among which three species are regarded to be new to science, and one belonging to a new genus. The whole species contained in the present paper are listed as follows:

Order Phrynophiurida

Family Trichasteridae

1. Astroceras annulatum MORTENSEN

2. Trichaster elegans LUDwIG

Family Gorgonocephalidae

1) Contributions from the Zoological Laboratory, Kyūsyū Imperial University, No. 169; Papers from the Amakusa Marine Biological Laboratory, No. 91. 
3. Astrocladus coniferus (DöDERLEIN)

4. Astroboa arctos MATsUmoto

5. Astroglymma sculptum (DöDERLEIN)

Order Gnathophiurida

Family Amphiuridae

6. Ophiactis modesta BROCK

7. Ophiactis savignyi (MüLLER et TROsCHEL)

8. Ophiophragmus japonicus Matsumoto

9. Amphipholis japonica Matsumoto

10. Amphipholis kochii LÜTKEN

11. Amphiura estuarii Matsumoto

12. Amphiura euopla CLARK

13. Amphiura lütkeni DUNCAN

14. Amphiura pachybactra MURAKAMI

15. Amphiura syntaracha CLARK

Family Ophiotrichidae

16. Ophiothrix koreana DUNCAN

17. Ophiothrix marenzelleri KGHLER

18. Ophiothrix stabilis KCEHLER

19. Ophiotrichoides nereidina (LAMARCK)

20. Ophiogymna elegans LJUNGMAN

21. Ophiomaza cacaotica EYMAN

22. Ophiomaza kanekoi MATsumoto

23. Ophiothela dance VERRILL

Order Chilophiurida

Family Ophiolepididae

.24. Ophiura kinbergi (LJUNGMAN)

25. Ophioplocus japonicus CLARK

Family Ophiodermatidae

26. Ophiarachnella differens sp. nov.

27. Ophiarachnella gorgonia (MüLLER et TROSCHEL)

28. Ophiostegastus instratus gen. et sp. nov.

Family Ophiochitonidae

29. Ophionereis porrecta LYMAN

30. Ohiocrasis latens sp. nov.

31. Ophiocrasis marktanneri Matsumoto

Family Ophiocomidae

32. Ophiomastix mixta LüTKEN 
Among these Ophiurans, Ophiactis savignyi is an intertropical species, reaching as far as Misaki northwards. Trichaster elegans, Astrocladus coniferus, Astroglymma sculptum; Ophiactis modesta, Amphiura lïtkeni, Ophiothrix koreana, Ophiotrichoides nereidina, Ophiogymna elegans, Ophiomaza cacaotica, Ophiothela dance, Ophiura kinbergi, Ophiarachnella gorgonia, Ophionereis porrecta and Ophiomastix mixta are Indo-Pacific in their distribution. Both these intertropical and Indo-Pacific species are referable to the tropical elements. Astroceras annulatum, Astroboa arctos, Amphipholis japonica, Amphipholis kochii, Amphiura cestuarii, Amphiura euopla, Amphiura pachybactra, Amphiura syntaracha, Ophiothrix marenzelleri, Ophiothrix stabilis, Ophiomaza kanekoi, Ophiarachnella differens, Ophiostegastus instratus, Ophiocrasis latens and Ophiocrasis marktanneri have been known only from vicinities of Honsyū, and are thought to represent the Honsyū species. Ophiophragmus japonicus and Ophioplocus japonicus had been also considered to belong to Honsyū species, but recently the former was reported from the Gulf of Thai (Siam) and Amboina by KceHLER (1930), and the latter from Hong Kong by MoRTENSEN (1934). At any rate, the Ophiuran fauna of Amakusa is deemed to be constituted mainly of tropical and Honsyū elements.

I must here express my hearty gratitude to Professor Dr. H. OHSHIMA for his kind guidance given to me during the investigation, and for giving me the opportunity of studying the valuable material preserved in the Amakusa Marine Biological Laboratory. I wish also to tender my thanks to my colleague, Mr. T. KaWAHARA for his kind assistance in taking a photograph for illustration.

\section{SYSTEMATICS}

Order Phrynophiurida

Family Trichastéridae

\section{Astroceras annulatum MORTENSEN}

Astroceras pergamena: 'Matsumnto, 1917, p. 35, fig. 7, b.

Astroceras annulatum: Mirtensen, 1933, p. 47, figs. 32 \& 33, b, pl. V, figs. 20-25.

Localities.-Tomioka, Aug. 23, 1942; eight specimens (caught in "kasi-ami"). Same locality; five specimens.

Distribution.-Sagami Sea. Near the Goto Islands. 
The present species is a small six-armed Ophiuran, found clinging to a colony of Melitodes sp. The colour in life is yellowish white on the disk and light pinkish on the arms. At first CLARK and MATsumoto described it as a young form of A. pergamena, but later it was separated from $A$. pergamena by MORTENSEN as a distinct species.

\section{Trichaster elegans LUDwIG}

Ludwig, 1878, p. 213, pl. V, figs. 1-9. Матsumoto, 1917, p. 38, fig. 8, pl. II, figs. 7-8.

Localities.-Tomioka, Nov. 1, 1940; one specimen (caught in "kasi-ami"). Same locality; four specimens.

Distribution.-Tanabe Bay. Pacific Ocean. India.

This is an elegant Ophiuran coloured yellowish gray on the dorsal side of disk and arms, and is occasionally caught in "kasiami" at Tomioka.

Family Gorgonocephalidae

3. Astrocladus coniferus (DöDERLEIN)

Astrophyton pardalis: DóderLein, 1902, p. 323.

Astrophyton coniferum: DöDERLEIN, ditto, p. 325.

Astrocladus dofleini: DóderLern, 1910, p. 256.1)

Astrocladus coniferus : DóderLein, 1911, p. $46 \& 75$, pl. II, figs. 7-7a, pl. IV, figs. 1-3a, pl. VII, figs. 5-6a \& 16. Матьмото, 1917, p. 77, fig. 23.

Localities.-Uze, 'Tomioka, June 1928; one specimen (probably caught in "kasi-ami"). Sakasegawa, April 8, 1932; one specimen. Tomioka, Jan. 4, 1942; one specimen (caught in "kasi-ami").

Distribution.-Misaki. Sagami Sea. Suruga Gulf. Off Omae Zaki. Kagosima. Colnett Strait. Eastern Sea. Fusan, Tyōsen. Wladiwostok. Indian Ocean.

\section{Astroboa arctos Matsumoto}

(Plate I, figs. 2-3)

Matsumoro, 1915, p. 57.-1917, p. 80, fig. 24.

Localities.-Tomioka; five specimens (caught in "kasi-ami"). Unzen Zaki, Tomioka, June 4, 1928; two specimens.

Distribution.-Misaki.

Though the colour of our specimens is purplish black above in life like that of $A$. nigra DöDERLEIN, it becomes dark grayish 
brown above and dark yellowish brown below in alcohol, as described by Matsumoto. Further, resembling the type of $A$. arctos, the double rows of hook-bearing granules are limited to the terminal part of arm, the stout proximal part of arm being free from them. This Ophiuran is often found among the catch of "kasiami".

\section{Astroglymma sculptum (DöDERLEIN)}

(Text-fig. 1; Plate I, fig. 1)

Astrophyton sculptum: DöDerLein, 1896, p. 299, pl. XVIII, figs. 29-29b.

Astrodactylus sculptus: DöDerLein, 1911, p. 56, fig. 13, a-b.

Astroglymma sculptum: DöDerLerN, 1927, p. $47 \& 96$, pl. I, figs. 3-4, pl. V, fig. 13.1 MoRTENSEN, 1934, p. 5, pl. VI.

Localities.-Siroiwa Zaki, Tomioka, Aug. 21, 1931; one specimen (probably caught in "kasi-ami"). Tomioka; three specimens (caught in "kasi-ami").

Distribution.-Hong Kong. Amboina. Kei Islands.

The largest specimen before me is $55 \mathrm{~mm}$ in diameter of disk. The colour in life is deep red, while in alcohol, it fades to dirty gray or red, with a number of dirty purplish speckles on the dorsal side of disk. That the madreporites are five in number, one on each interradius, that the ventral arm plates are wanting,

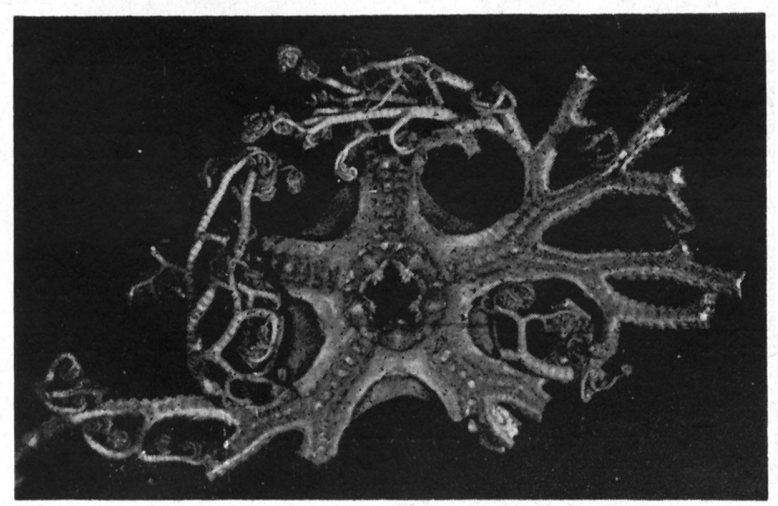

Fig. 1. Astroglymma sculptum; from below. $\times \frac{4}{7}$.

and that the hook-spines have only one branch on a side, are remarkable characters of this species. Though the present species

1) "Abhandl. Bayer. Akad. Wiss., XXXI, 6", not accessible to me. 
has not so far been reported from Nippon, it is common at Tomioka, usually found among the catch of "kasi-ami".

\section{Order Gnathophiurida \\ Family Amphiuridae \\ 6. Ophiactis modesta BROCK}

BRock, 1888, p. 482. MАтsumoto, 1917, p. 156, fig. 38.

Localities.--Tomoé Zaki, Tomioka, Aug. 14, 1931; numerous specimens. Tomioka, May 5, 1940; four specimens (caught in "kasi-ami"). Same locality, Aug. 15, 1941; nine specimens. Same locality, April 24, 1942; two specimens. Same locality, Aug. 15, 1942 ; one specimen.

Distribution.-Misaki. Palao. Amboina. Thursday Island.

Those specimens dated Aug. 14, 1931 were found creeping out from a sponge, and show that they reproduce by schizogony, the body being asymmetrical without exception.

\section{Ophiactis savignyi (MüLlER et Troschel)}

Ophiolepis savignyi: MülLER et TROSCHEL, 1842, p. 95.

Ophiactis savignyi: Lyman, 1882, p. 115. Clark, 1915, p. 265. Matsumoto, 1917, p. 158, fig. 39.

Localities.-Near Kakize, Tomioka, May 5, 1940 ; six specimens. Tomioka, Aug. 15, 1941; two specimens (caught in “kasi-ami"). Ebisu Bana, Tomioka; three specimens.

Distribution.-Misaki. Izu. Tyōsen Seas. Malaysian Waters. Australia. Palao. Gulf of California. West Indies.

\section{Ophiophragmus japonicus Matsumoto}

Matsumoto, 1915, p. 70. Clark, 1915, p. 239. Matsumoto, 1917, p. 183, fig. 48, pl. IV, fig. 3.

Localities.-Tomoé Bay, Tomioka, Aug. 14, 1929; three specimens. Tomioka Bay; three specimens.

Distribution.-Mutu Bay. Off Oginohama, Rikuzen. Enoura, Suruga. Mikawa Bay. Ise Bay. Matoya Bay. Ago Bay. Beppu Bay. Off Namami, Kagosima Gulf. Thai Bay. Amboina. 


\section{Amphipholis japonica Matsumoto}

Matsumoto, 1915, p. 71. Clark, 1915, p. 241. Matsumoto, 1917, p. 186, fig. 49.

Localities.--Siroiwa Zaki, Tomioka; numerous specimens. Near Kakize, Tomioka; numerous specimens.

Distribution.-Misaki. Izu. Tomo, Bingo. Asami Bay, Tusima. Simabara, Hizen. Akune, Satuma.

A. japonica is abundant at Tomiokamespecially at Siroiwa Zaki and near Kakize, living on the bottom of fine sand under a stone at the intertidal zone. It is a small viviparous Ophiuran, being pregnant all the year round.

\section{Amphipholis kochii LÜTKEN}

Amphipholis kochii : LüTKen, 1872, p. 10, pls. I-II, fig. 6. ClarK, 1915, p. 241. Matsuмото, 1917, p. 192, fig. 52, pl. IV, fig. 2.

Amphiura kochii: Lyman, 1882, p. 146.

Localities.-Ebisu Bana, Tomioka, April 5, 1928; two specimens. Siki, April 6, 1931; one specimen. Ebisu Bana, Tomioka, May 29, 1942; numerous specimens.

Distribution.-Hakodate. Mutu Bay. Aomori Bay. Misaki. Izu. Wladiwostok.

\section{Amphiura restuarii Matsumoto}

Matsumoto, 1915, p. 73.-1917, p. 208, fig. 57.

Locality.-Near the laboratory, Tomioka, April 13, 1941; five specimens.

Distribution.-Misaki. Matoya Bay. Ago Bay. Gokasyo Bay. Nanao Bay.

The present species is obviouisly related to A.vadicola Matsuмото, but is by no means misled to it, being distinguished by the larger radial shields, by the coarser. scales around the radial shield, and by, the well developed dorsal arm plates from the first proximal. At Tomioka, it is also found buried in mud near the laboratory; this mode of living is in accord with what MATsumoto already presumed.

12. Amphiura euopla CLARK

Clark, 1911, p. 144, fig. 57. Matsumoto, 1917, p. 201, fig. 55. 
Localities.-Kameura Bay, Simo Sima, May 1, 1934; seventeen specimens. Near the laboratory, Tomioka, April 13, 1941; two specimens.

Distribution.-Misaki. Enosima, Sagami. Suruga Gulf. Izuhara, Tusima.

The specimens before me are somewhat different from the type described by Clark, but agree well with Matsumoto's description and figures, though the ventral interbrachial spaces are not bare. They are rather small, measuring 3.5 to $5.5 \mathrm{~mm}$ across the disk.

\section{Amphiura lïtkeni DUNCAN}

Amphiura lütkeni: Duncan, 1879, p. 464, pl. X, fig. 17. ClarK, 1915, p. 228. Matsumoto, 1917, p. 208.

Amphiura duncani : Lrman, 1882, p. 143.

Localities.-Tomioka, Aug. 21, 1942; one specimen (caught in "kasi-ami"). Same locality, Aug. 22, 1942; two specimens.

Distribution:-Tyōsen Seas. Malaysian Waters.

This is a delicate, but handsome Ophiuran, the disk of which is easily broken when pulled out from the shelter. The ground colour in life is white, ornamented with red markings on the dorsal side of disk and arms. This species is met with very rarely.

\section{Amphiura pachybactra MURAKAMI}

Murakami, 1942, p. 17, fig. 7.

Localities.-Ebisu Bana, Tomioka, May 29, 1942; five specimens. Same locality; four specimens.

Distribution.-Sitaru, Izu.

This species is one of the common Ophiurans at Tomioka, living under stones on the bottom of fine sand at the intertidal zone.

\section{Amphiura syntaracha CLARK}

(Text-fig. 2)

CLARK, 1915, p. 232, pl. V, figs. 14-15.

Localities.-Siki, April 6, 1931; one specimen. Same locality; three specimens. Ebisu Bana, Tomioka; four specimens.

Distribution.-Mouth of the Gulf of, Tokyo. 
Fig. 2. Amphiura syntaracha.

A. From above. 'B. From below.

C. Arm spines of one side of an arm joint near disk.

D. Arm spines of one side of an arm joint at some distance from disk. $\times 15$.

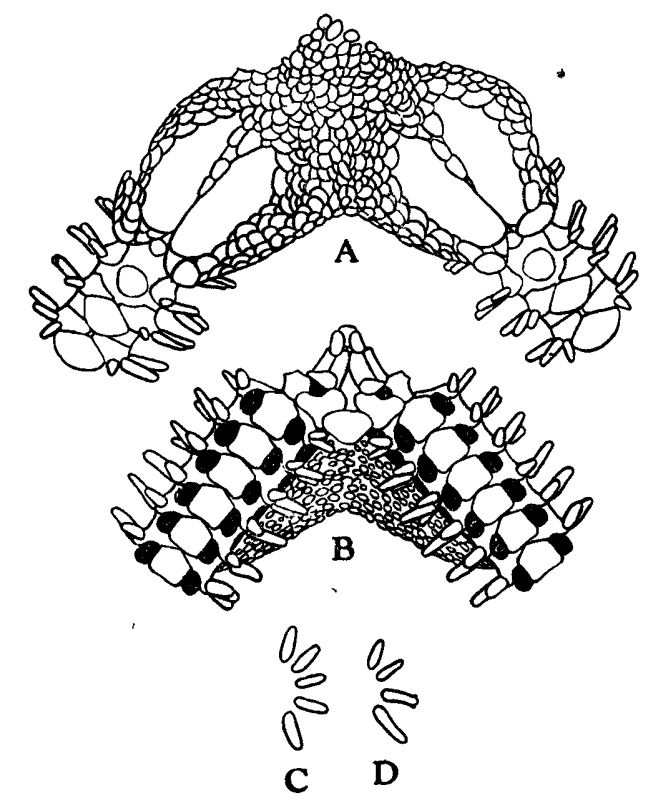

Family Ophiotrichidae

16. Ophiothrix koreana DunCAN

Duncan, 1879, p. 473, pl. XI, figs. 28-32. Clark, 1911, p. 257, figs. 127-128.-1915, p. 273. Matsumoto, 1917, p. 220, pl. IV; fig. 7.

Localities.-Tomoé Zaki, Tomioka, April 7, 1928; three specimens. Same locality, June 11, 1933; one specimen. Hutaé, Feb. 26, 1935; six specimens. Tomoé Zaki, Tomioka, April 30, 1940; one specimen. Tomioka, May 5, 1940; one specimen (caught in "kasi-ami"). Same locality, Aug. 15, 1941; three specimens. Same locality; thirty-five specimens. Ebisu Bana, Tomioka; two specimens.

Distribution.-Hakodate. Gulf of Tokyo. Uraga Channel. Sagami Sea. Suruga Gulf. Sea of Nippon. Nanao Bay. Tyōsen Strait. Eastern Sea. Southwest of the Gotō Islands. Kagosima Gulf. Off Satuma. Philippine Islands. Moluccas. Banda. Amboina. Kei Islands.

\section{Ophiothrix marenzelleri KœHLER}

KЕнLеR, 1904, p. 103, figs. 76-78. Mатsuмото, 1917, p. 220.-1941, p. 342, fig. 8.

Locality.-Tomoé Zaki, Tomioka, April 7, 1928; six specimens. 
Distribution.-Mutu Bay. Misaki. Entrance to the Gulf of Tokyo, Off Zyōgasima, Sagami Sea. Enosima. Off Ayukawa. Kominato. Toba, Sima. Matoya Bay. Tomo, Bingo. Asami Bay, Tusima. Kagosima Gulf.

\section{Ophiothrix stabilis KGHLER}

K⿷匚LER, 1904, p. 84, figs. 46-49. Matsumoto, 1917, p. 224.

Localities.-Tomoé Zaki, Tomioka, April 7, 1928; two specimens. Same locality, June 11, 1933; six specimens. Same locality, Feb. 27, 1935; six specimens. Same locality, April 30, 1940; two specimens. Tomioka; five specimens (caught in "kasi-ami").

Distribution.-Misaki. Kōbe.

In our specimens, the dorsal arm plates are rough or thorny on the surface, especially at the distal part of them, though this feature was not noticed by KøHLER and Matsumoto. But the other characters are quite in accord with those of the type.

\section{Ophiotrichoides nereidina (LAMARCK)}

Ophiura nereidina: LAMARck, 1816, p. 544.

Ophiothrix nereidina: MülLER et TRoscheL, 1842, p. 115. C C мото, 1917, p. 224, fig. 61, pl. IV, fig. 6 .

Ophiotrichoides nereidina: C C LRK, 1938, p. 306.

Locality.-Kakize, Tomioka, Aug. 4, 1929; one specimen.

Distribution.-Misaki. Simoda, Izu. Okinawa. Yaéyama. IndoPacific.

\section{Ophiogymna elegans LJUNGMAN}

Clark, 1915, p. 286, pl. XII, figs. 7-8. Køaler, 1922, p. 281, pl. XLIII, figs. 3-8, pl. CIII, fig. 7. Murakami, 1942, p. 20.

Localities.-Tomioka, May 5, 1940; one specimen (caught in "kasi-ami"). Same locality; fourteen specimens.

Distribution.-Izu. Syōnan (Singapore). Hong Kong. Philippine Islands. Sulu Archipelago. Gulf of Davao.

\section{Ophiomaza cacaotica LYMAN}

Lyman, 1871, p. 9, pl. I, fig. 15. Döderlein, 1896, p. 298, pl. XVII, figs. 26-26a. Clark, 1915, p. 283. KєнLER, 1922, p. 299.

Locality.-Tomioka, Aug. 24, 1942; two specimens (caught in "kasi-ami"). 
Distribution.-Zanzibar. Trincomalee. Mergui Archipelago. Syōnan. Sunda Islands. Java. Sea of Nippon. Hong Kong. China Sea. Sulu Archipelago. Kei Islands. Torres 'Strait. Thursday Island. East coast of Australia. New Caledonia.

The specimens before me are very elegant; the disk is streaked radially with white and purplish brown, and the arms are ornamented with a broad white longitudinal stripe hemmed by purplish brown. They were found tightly clinging to a crinoid caught in "kasi-ami".

\section{Ophiomaza kanekoi Matsumoto}

Matsumoto, 1917, p. 227, fig. 66.

Localities.-Tomoé Zaki, Tomioka, Sept. 20, 1930; eight specimens. Tomioka; two specimens (caught in "kasi-ami").

Distribution.-Simabara, Hizen.

This Ophiuran is common at Tomioka, occurring always closely adhering to a crinoid, which lives outside of Tomoé Zaki where the water is several meters deep. The colour in life is entirely blackish purple.

\section{Ophiothela dance VERRILL}

Ophiothela dance: Verrild, 1869, p. 391. Matsumoto, 1917, p.230, fig. 67, pl. IV, fig. 8. Ophiothela isidicola. LürkeN, 1872, p. 92, pls. I-II, figs. $4 \mathrm{a}-4 \mathrm{~g}$.

Ophiothela verrilli: Duncan, 1879 , p. 477 , pl. XI, fig. 33.

Ophiothela dance var. involuta: KEHLER, 1898, p. 88.

Localities.-Tomioka, April 23, 1942; six specimens (caught in "kasi-ami"). Same locality; four specimens.

Distribution.-Misaki. Izu. Tyōsen Seas. Strait of Taiwan (Formosa). Indo-Pacific.

\section{Order Chilophiurida}

Family Ophiolepididae

\section{Ophiura kinbergi (LJUNGMAN)}

Ophioglypha kinbergi : LuUngman, 1866, p. 116.1)

Ophioglypha sinensis : Lyman, 1871, p. 12, pl. I, figs. 1-2.

Ophioglypha ferruginea: LyMAN, 1878, p. 68, pl. III, fig. 76.

Ophiura kinbergi: ClaRk, 1911, p. 37, fig. 9.-1915, p. 321. Matsumoto, 1917, p. 271, fig. 73.

1) "Öfv. K. Vet. Akad. Föhr., XXVII", not accessible to me. 
Locality.-Tomioka Bay; three specimens.

Distribution.-Off Yokohama. Uraga Channel. Misaki. Mikawa Bay. Ise Bay. Matoya Bay. Inland Sea. Tomo, Bingo. Beppu Bay. Hakata Bay. Tusima. Eastern Sea. Off Ettigo, Sea of Nippon. Indo-Pacific.

\section{Ophioplocus japonicus CLARK}

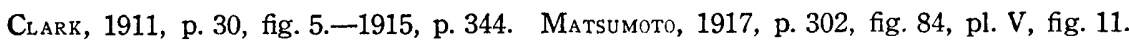

Locality.-Tomioka; three specimens.

Distribution.-Entrance of the Gulf of Tokyo. Misaki. Enosima. Odawara. Bōsyū. Suruga. Izu. Ayukawa. Hong Kong.

The present species occurs abundantly around Tomioka, generally living under stones near the low-tide mark. This is one of the most common Ophiurans along the entire southern coast of Honsy $\bar{u}$ and its vicinities. The distribution extends southwards, reaching as far as Hong Kong, as reported by MORTENSEN.

\section{Ophiarachnella differens sp. nov. ${ }^{1)}$}

(Text-fig. 3)

Disk $11 \mathrm{~mm}$ in diameter; arms varying in length, but the longest available $35 \mathrm{~mm}$ long. Breadth of arm $2.5 \mathrm{~mm}$ at base.

Disk convex above, pentagonal, covered with fine, more or less spaced granules, but the radial shields, trio of plates at the base of arm, a plate at the middle of each interradial border and a number of scales near the periphery are entirely bare. Radial shields rather small, somewhat elliptical, longer than broad, well separated from each other. Central plate of trio somewhat smaller than the radial shield, rounded; other two small, rounded triangular. Interbrachial spaces below also covered with fine granules, but the several scales are free from them. Genital slits large, as long as three arm joints.

Oral shields naked, moderate in size, roughly triangular in shape, with angles quite blunt and margins somewhat concave. Supplementary oral shields also bare, small, semicircular, close to the oral shield. Adoral shields small, at sides of oral shield, gran-

1) Differens, signifying different, in reference to the disk covering different" from that of the allied species. 
ulated at the distal part. Oral plates concealed by a granulation. Oral papillae eight or nine on a side of an oral angle; the proximal ones subequal, thick, but blunt at the tip, while the outer ones flat, broad, truncated at the end, but the distalmost one is terminating to a point upwards so as to overlap the following two. Two infradental papillae present at the tip of one oral angle.

Dorsal arm plates thick and stout. At first they are tetragonal, the distal border being convex and the lateral sides diverging without. The proximal border of dorsal arm plate becomes shorter and shorter as it goes distally, and finally disappears so as to make the plate triangular. They are in contact with each other till near the tip of arm. First ventral arm plates rather large, broader

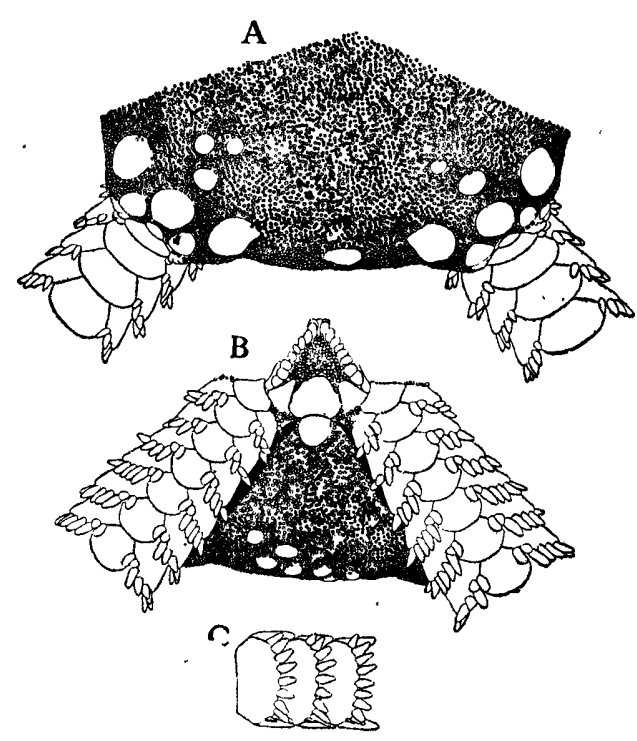

. Fig. 3. Ophiarachnella differens.

A. From above. B. From below.

C. Side view of three arm joints near disk. $\times 5$. than long, distal border convex, proximal one making a narrow angle turning to the mouth slit. Following ones heptagonal with a distal angle very rounded, broader than long, but becoming pentagonal and longer than broad distally. They are well in contact with each other at the proximal half of arm. No pores between basal ventral arm plates. Side arm plates thick and stout, as high as arm joint, but not meeting either above or below; each one carries nine stout, conical, subequal arm spines, which are less than one half of joint in length and are reduced in number to eight, seven, six distally and finally to three at the tip of arm. Tentacle scales two to each pore at the proximal two-thirds of arm; adradial one larger than the abradial one which is overlapping the base of undermost arm spine. Farther out they fall to one to each pore.

Colour in life, dirty gray, with dark spots on the disk; some 
scales near the periphery white with rusty shade at the centre. Arms banded with rust; the dorsal arm plates, some of which have three white speckles on the outer margin, are darker than the side arm plates so as to make a broad longitudinal stripe. Ventral side of disk whitish; that of the terminal part of arm yellowish gray. Arm spines yellowish gray distally and whitish towards base.

Locality.-Tomoé Zaki, Tomioka, Aug. 15, 1943; one specimen.

This Ophiuran represented by a single individual in the collection, was found living under a stone on the sandy bottom, but the characters are so remarkable that it well deserves to stand as a distinct species. It is closely allied to $O$. infernalis (MÜLLER et TROSCHEL), O. similis (KøHLER) and O. megalaspis CLARK, but it is easily distinguished from $O$. infernalis by the coarser and more spaced granulation of disk, and by the thicker and stouter arm plates, from $O$. similis by having more numerous bared scales on the disk, and from $O$. megalaspis by the smaller and more broadly separated radial shields.

\section{Ophiarachnella gorgonia (MÜLLER et TROSCHEL)}

Ophiarachna gorgonia: MürLER et Troscher, 1842, p. 105.

Pectinuira gorgonia: LüTKEN, 1869, p. 33.

Ophiarachnella gorgonia : CLARK, 1909, p. 123.-1915, p. 305. Matsumoto, 1917, p. 323, pl. VI, fig. 7.

Locality.-Tomoé Zaki, Tomioka, June 29, 1930; two specimens.

Distribution.-Misaki. Suruga. Izu. Kagosima Gulf. Yaéyama. Indo-Pacific.

At first glimpse, this animal is liable to be mistaken for Ophioplocus japonicus occurring together with it, but the coloration of $O$. gorgonia is clearer than that of $O$. japonicus. Further, they are quite different in the other characters.

\section{Ophiostegastus gen. nov. ${ }^{1)}$}

Disk closely covered with granules both above and below. Radial shields invisible. Oral papillae numerous. Arms more or less covered with a fine granulation. Arm plates well developed.

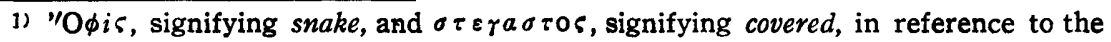
disk and arms covered with granules.
} 
Arm spines short and thick. Tentacle scales two to each pore. Genital slits also two in each interradius.

Type species; Ophiostegastus instratus.

The new genus is obviously related to Pectinura, Ophiopezella, Ophiochceta, Ophiarachnella and Ophiochasma in having short arm spines, two tentacle scales to each pore, and two genital slits in each interradius, but the granulation of arms makes a remarkable character to distinguish it from the above enumerated genera. Besides the genotype, it contains Ophiocryptus pacificus MURAKAMI, which at first I thought belonging to Ophiocryptus, but it must be strictly removed from the said genus for the rèason of having two, not four, genital slits in each interradius.

28. Ophiostegastus instratus sp. nov."

(Text-fig. 4)

Ophiarachnella infermalis: Matsumoto, 1917, p. 324, fig. 90. (Non Mürler et Troschel, 1842.)

Disk $7 \mathrm{~mm}$ in diameter; arms $21 \mathrm{~mm}$ long. Disk pentagonal, flat, closely covered with fine granules except the trio of plates at base of arm and a single marginal scale at the middle of each interradial border, which are more or less bare. Radial shields invisible. Interbrachial spaces below, adoral shields and oral plates also covered with a close granulation. Oral shields naked, triangular in shape, with angles rounded, about as wide as long. Supplementary oral shields present distal to the oral shield, smaller than the latter, half-moon shaped, more or less covered with granules. Oral papillae nine or ten on a side, subequal, blunt at the tip, but the outermost one is largest and pointed at the tip, overlapping the following two. Genital slits rather small, two and a half times as long as a joint.

Arms also granulated, especially the side arm plates so. The dorsal and ventral arm plates are mostly naked, but becoming completely covered with granules very near the tip of arm., Dorsal arm plates convex, tetragonal, as wide as long, distal border markedly rounded and very much longer than the proximal one, but becoming triangular in shape at the terminal part of arm. Those of the proximal half of arm are in contact with each other, but become separated from each other distally. First ventral arm

1) Instratus, signifying uncovered, in reference to the bared oral shields. 
plates rather large, about as broad as long, very rounded, with a proximal lobe. Succeeding two hexagonal and slightly broader than long, but becoming octagonal or heptagonal and longer than broad distally. They are in contact with each other except those near

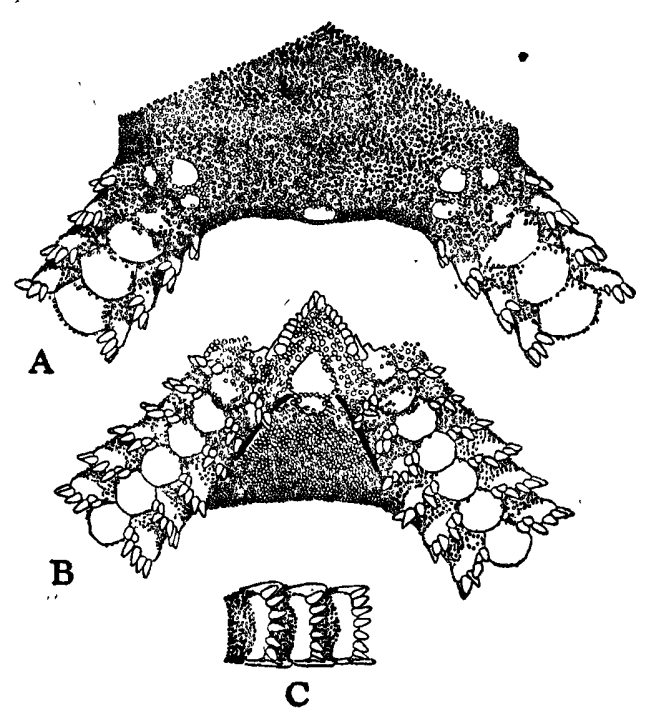

Fig. 4. Ophiostegastus instratus.

A. From above. B. From below.

C. Side view of three arm joints near disk. $\times 7$. the tip of arm. Side arm plates broad and somewhat prominent, markedly granulated at the proximal two-thirds of plate, not meeting both above and below except the distal part of arm, each of which carries seven thick, conical, subequal arm spines near the disk, which are about one-third of a joint in length and are reduced to four in number near the end of arm. Tentacle scales two to each pore, small; the inner one slightly larger than the outer one, which is overlapping the base of undermost arm spine.

Colour in life; buffy citrine above, with black spots and short irregular lines on the disk; arms are ornamented with a dark longitudinal stripe and rust bands. Ventral side whitish.

Locality.-Siroiwa Zaki, Tomioka, July 16, 1943; one specimen.

The Ophiuran described and figured by MATSUMOTO as a variety of Ophiarachnella infernalis in 1917 is undoubtedly conspecific with the present species. It is easy to distinguish it from the other member of this genus, $O$. pacificus (MURAKAMI, by a different mode of granulation of disk. The oral shields, trio of plates at base of arm and a single marginal plate at each interradial border are more or less bare in $O$. instratus, while in $O$. pacificus, they are completely concealed by granules. 


\section{Family Ophiochitonidae}

\section{Ophionereis porrecta LYMAN}

Lyman, 1860, p. 260. Clark, 1915, p. 289. Matsumoto, 1917, p. 334, fig. 93.

Localities.-Tomioka, Sept. 3, 1941; four specimens (caught in "kasi-ami"). Same locality; one specimen.

Distribution.-Izu. Tyōsen Strait. Okinawa. Andaman. Torres Strait. Fiji Islands. Honolulu.

\section{Ophiocrasis latens sp. nov. ${ }^{1)}$}

(Text-fig. 5)

Disk $5 \mathrm{~mm}$ in diameter; arms $27 \mathrm{~mm}$ long. Breadth of arm $1 \mathrm{~mm}$ at base. Disk rounded pentagonal, covered with a coating of fine, delicate scales. Radial shields small, triangular, more than three times as long as broad, well separated. Interbrachial spaces below also covered with a fine scaling. Genital slits'very conspicuous.

Oral shields of moderate size, rhomboidal, proximal borders longer than distal ones, with angles rounded. Adoral shields small,

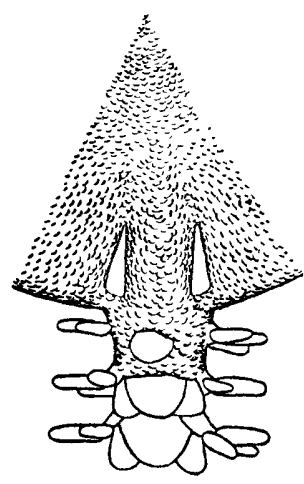

A

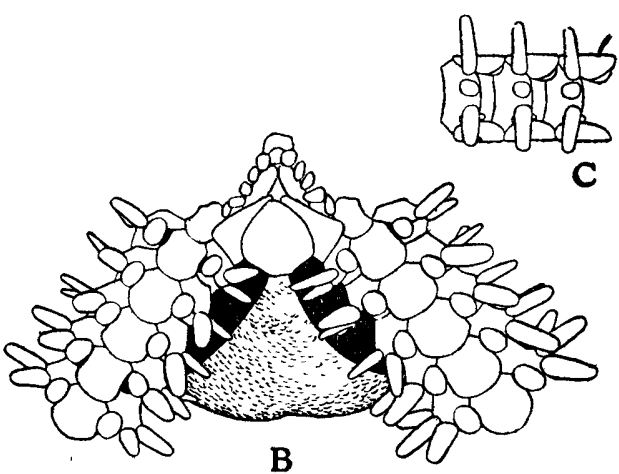

Fig. 5. Ophiocrasis latens.

A. From above. B. From below.

C. Side view of three arm joints near disk. $\times 10$.

longer than broad, narrow within, enlarged distally, not meeting on the interradial line. Oral plates also small, higher than broad.

\footnotetext{
1) Latens, signifying hidden, in reference to the rudimentary secondary supplementary dorsal arm plates being not visible from above.
} 
Oral papillae five in number on a side; the proximal one thick and rounded; following three rather flat, blunt at the tip; the distalmost one conical, pointed at the tip. Teeth four or five on a jaw, squarish, thick; the undermost one is the smallest and less than one half of the following in size.

Arms somewhat narrow at base, broadest at some distance from the disk, beyond gradually tapering. First dorsal arm plates small, oval, separated from the second; following ones triangular, with a very rounded distal angle, wider than long, but becoming hexagonal and also somewhat broader than long at the middle of arm; beyond them they are again triangular in shape, with an angle turning proximad, and about as wide as long. They are well in contact with each other till near the tip of arm. Supplementary dorsal arm plates small, somewhat triangular in shape, with a rounded distal margin. Secondary ones, one on each side, rudimentary, not visible from above. First ventral arm plates small, pentagonal, longer than broad. Following ones tetragonal, with angles rounded and lateral sides concave; about as long as broad, but becoming pentagonal and longer than broad at the terminal part of arm; they are in contact with each other except those at the tip of arm. Side arm plates not meeting either above or below, carrying three flat, subequal, blunt arm spines, which are about as long as a joint in length. Tentacle scales single to each pore, large, flat, elliptical.

Colour (dried from alcohol); disk olive buff, reticulated with sepia; arms gray, banded with sepia; ventral side whitish.

Localities.-Tūzi Zima, April 23, 1940; one specimen. Siroiwa Zaki, Tomioka, Aug. 2, 1943; one specimen (collected by Mr. KAWAHARA).

The new species is allied to $O$. dictydisca CLARK in several features, but differs from it in the less developed secondary supplementary dorsal arm plates and in the rhomboidal oral shields. It is also distinguished from O. marktanneri Matsumoto by the shape of dorsal arm plates, by the less developed secondary pieces, by the more distinct radial shields, and by the more stout arm spines. This Ophiuran is generally found living under a stone at the intertidal zone. 


\section{Ophiocrasis marktanneri Matsumoto}

Matsumoto, 1915, p. 90.-1917, p. 338, fig. 94, pl. vII, fig. 3.

Localities.-Siroiwa Zaki, Tomioka, April 22, 1940; one specimen. Ebisu Bana, Tomioka, May 29, 1942 ; one specimen.

Distribution.-Misaki. Sagami. Izu.

\section{Family Ophiocomidae}

\section{Ophiomastix mixta LÜTKEN}

LütKen, 1869, p. 44. Clark, 1911, p. 256, fig. 126.-1915, p. 296.' Matsumoto, 1917, p. 348, fig. 97.

Localities.-Ebisu Bana, Tomioka, Aug. 6, 1929; one specimen. Tomoé Zaki, Tomioka, Aug. 14, 1931; three specimens. Siroiwa Zaki, Tomioka, March 7, 1939; one specimen.

Distribution.-Misaki. Enosima. Izu. Yaéyama. Indo-Pacific.

This is a beautiful Ophiuran, coloured deep red; the arms being banded with yellowish white on the terminal part. It is also found commonly at Tomioka near the low-tide mark, and is easily misled to Ophiocoma in the preserved state, but is different from it in that the granules of disk become elongated near the periphery.

$$
\text { (Amakusa Marine Biological Laboratory, Kumamoto-kèn) }
$$




\section{IITERATURE}

BRock, J 1888 Die Ophiurıdenfauna des indischen Archipels Zeitschr wiss Zool, XLVII, 3, pp 465-539

ClaRk, H L 1909 Notes on some Australian and Indo Pacific Echınoderms Bull Mus Comp Zool, LII, 7, pp 109-135, pl I

- 1911 North Pacific Ophiurans in the collection of the United States National Museum U S Nat Mus, Bull 75, pp 1-302

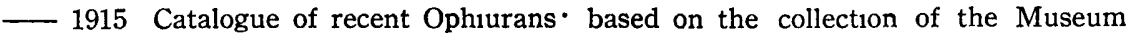
of Comparatıve Zoology Mem Mus Comp Zool, XXV, 4, pp 163-376, pls $\mathrm{I}-\mathrm{XX}$

1921 The Echınoderm fauna of Torres Strait Dept Mar Bıl Carnegie Inst, X, pp 1-223, pls I-XXXVIII

- 1938 Echınoderms from Australıa Mem Mus Com Zool, LV, pp 1-596, pls I-XXVIII

Doderlein, L 1896 Bericht uber die von Herrn Prof Semon bei Amboina und Thurs day Island gesammelten Ophiuroidea Semon Zool Forschungsr, V pp 277300 , pls XIV-XVIII.

1902 Japarische Euryaliden Zool Anz, XXV, pp 320-326

- 1911 Uber Japanısche und andere Euryalae Abhandl math phys Kl K Bayer Akad Wiss, Suppl Bd II, Abhandl 5, pp 1-123, pls I-IX

Duncan, P M 1879 On some Ophiuroidea from Korean Seas Journ Linn Soc, Zool , XIV, pp 445-482, pls IX-XI

KøнLеR, R 1898 Échınodermes recueilis par l'Investıgator dans l'Océan Indien II Les Ophiures hittorales Bull Scı France et Berg, XXXI, pp 54-124, pls II-V

1904 Ophrures nouvelles ou peu connues Mém Soc Zool France, XVII, pp

- 54-119

- 1905 Ophiures de l'Expedition du Siboga Pt II Ophiures littorales Leiden, pp 1-142, pls I-XVIII

1922 Ophiurans of the Philippine Seas and adjacent waters U S Nat Mus, Bull 100, V, pp 1-486, pls I-CIII

- 1930 Ophiures recuellies par le Docteur Th Mortrnsev dans les Mers d'Aus tralie et dans l'Archipel Malass Vidensk Medd fra Dansk naturh Foren, LXXXIX, pp 1-295, pls I-XXII

Lamarck, J B P 1816 Historre Naturelle des Anımaux sans Vertèbre II

Ludwig, H 1878 Trichaster elegans Morphologische Studien an Echınodermen, I, pp 213-221, pl V

LuTkEN, Ch 1869 Additamenta ad historiam Ophiuridarum 3 Afdelıng, pp 24-109

- 1872 Ophuridarum novarum descriptiones nonnullae Overs Kongl Danske Vid Selsk. Forh, pp 75-158, pls I-II

Lyman, Th 1860 Descriptions of new Ophiuridae, belonging to the Smithonian Institution and to the Museum of Comparative Zoology at Cambridge Proc Boston Soc Nat Hist, VII, 13, pp 252-262

1865 Ophiuridae and Astrophytidae Ill Cat Mus Comp Zool, 1, pp 1-200, pls I II

1871 Supplement to the Ophiuridae and Astrophytidae Ill Cat Mus Comp Zool, 6, pp 1-17, pls I-II 
1874 Ophiuridae and Astrophytidae, new and old. Bull. Mus. Comp. Zoöl., III. 10 , pp. 221-272, pls. I-VII.

1878 Ophiuridae and Astrophytidae of the "Challenger" Expedition. Part I. Bull. Mus. Comp. Zoöl., V, 7, pp. 65-168, pls. I-X.

1882 Report on the Ophiuroidea dredged by the Challenger. The voyage of the Challenger, Zool., V, pp. 1-386, pls. I-XLVIII.

MarkTAN NLR-TuRneretschir, G. 1887 Beschreibung neuer Ophiuriden und Bemerkungen zu bekannten. Ann. K. K.. Nat. Hofmus., II, 4, pp. 291-316, pls. XII-XIII.

Matsumoto, H. 1915 A new classification of the Ophiuroidea: with descriptions of new genera and species. Proc. Acad. Nat. Sci., Philadelphia, pp. 43-92.

1917 A monograph of Japanese Ophiuroidea, arranged according to a new classification. Journ. Coll. Sci., Imp. Univ. Tokyo, XXXVIII, 2, pp. 1-408, pls. IVII.

1918 On a collection of Ophiurans from the vicinity of Kinkwasan, with description of a new species. Annot. Zool. Japon., IX, 4, pp. 475-480.

1941 Report of the biological survey of Mutsu Bay. 36. Ophiuroidea of the Mutsu Bay and vicinities. Sci. Rep. Tōhoku Imp. Univ., Fourth Series, Biol., XVI, 3, pp. 331-344, pls. XXI-XXIII.

Mortensen, Th. 1933 Studies of Indo-Pacific Euryalids. Vidensk. Medd. fra Dansk naturh. Foren., XCVI, pp. 1-75, pls. I-V.

1934 Echinoderms of Hong Kong. Hong Kong Nat. Suppl., 3, pp. 1-14, pls. I-VIII.

MülleR, J. u. F. Troschel 1842 System der Asteriden, pp. 1-134, pls. I-XII.

Murakami, S. 1942 Ophiurans of Izu, Japan. Journ. Dept. Agric., Kyūsyū Imp. Univ., VII, 1, pp. 1-36.

1943 Report on the Ophiurans of Palao, Caroline Islands. Ditto, VII, 4, pp. 159-204.

1943 Report on the Ophiurans of Yaéyama, Ryukyu. Ditto, VII, 5, pp. 205-222.

- 1943 Ophiurans from some gulfs and bays of Nippon. Ditto, VII, 6, pp. 223-234.

VerriLl, A. E. 1869 On new and imperfectly known Echinoderms and Corals. Proc. Boston Soc. Nat. Hist., XII, pp. 381-391. 


\section{EXPLANATION OF PLATE I}

Fig. 1. Astroglymma sculptum (DödERLEIN); from above, $\times \frac{1}{2}$.

Fig. 2. Astroboa arctos Matsumoto; from above, $\times \frac{2}{3}$.

Fig. 3. Same specimen; from below, $\times \frac{2}{3}$. 

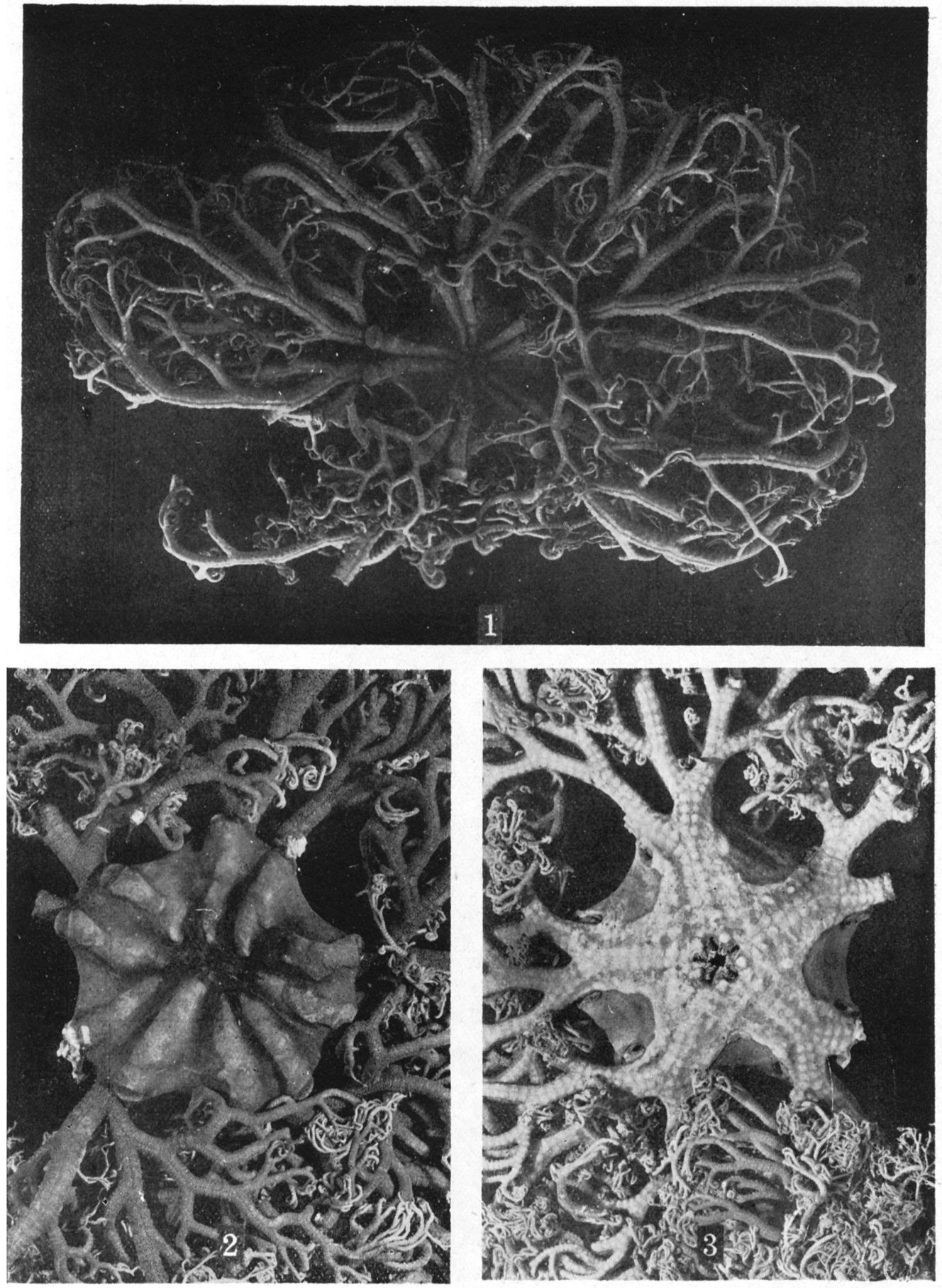